\title{
Turmeric Root and Annato Seed in Second-Cycle Layer Diets: Performance and Egg Quality
}

\section{-Author(s) \\ Laganá C \\ Pizzolante CC \\ Saldanha ESPB \\ Moraes JE de}

Researchers of APTA/DDD/SAA.

\section{mail Adress}

Christine Laganá

Caixa Postal 01

13.910-000. Monte Alegre do Sul, SP, Brazil.

E-mail: christine@apta.sp.gov.br

\section{nKeywords}

Annato, layers, second cycle, sorghum, turmeric.

\begin{abstract}
The objective of this study was to evaluate the effects of the inclusion of annato (Bixa orellana L.) and turmeric (Turmeric longa L.) in layer feeds on live performance, egg quality, and yolk pigmentation and depigmentation time. A number of 144 layers were distributed in a completely randomized experimental design, with four treatments with six replicates of six birds each. In the basal diet, sorghum replaced $50 \%$ of corn, and was supplemented or not with natural pigments to composse the following treatments: Control (0\% pigments), AS $(2.0 \%$ annato), TR ( $2 \%$ turmeric) and ASTR (1\% annato and $1 \%$ turmeric). Egg weight (g), egg production (\%), egg mass (\%), feed intake (g), feed conversion ratio $(\mathrm{kg} / \mathrm{dz}$ and $\mathrm{kg} / \mathrm{kg})$ and mortality were evaluated. The following egg quality parameters were evaluated: specific gravity (SG); yolk, albumen, and eggshell percentages, and yolk color. The treatments did not influence layer performance or egg quality parameters, except for egg production and yolk color. The dietary inclusion of $1 \%$ turmeric root and $1 \%$ annato seed promoted higher egg production. Diets containing annato resulted in more saturated, more intense, and redder yolk color, with increasing pigment deposition after day 10 , with maximum values obtained on day 28. Dried turmeric root did not promote good yolk pigmentation, resulting in higher presence of white in the yolk, which was stabilized on day 4. Three days after pigments were withdrawn from the feeds, yolk color faded in the treatments with annato inclusion.
\end{abstract}

\section{INTRODUCTION}

Corn is the main ingredient of poultry diets, accounting for $60-70 \%$ of feed costs. The use of feedstuffs alternative to corn and soybean meal is a strategy used by poultry nutritionists to reduce feeding costs, while ensuring the safety and the quality of the final product.

Some studies with layers have shown that sorghum can partially or completely replace corn in layer feeds with no negative effects on performance; however, a carotenoid source must be added to ensure egg yolk pigmentation (Casartelli et al., 2005; Assuena et al., 2008). Chickens are not capable of synthesizing color pigments, but can transport about $20-60 \%$ of the ingested dietary pigments to the yolk (Bartov \& Bornstein, 1980).

Yolk color intensity is a purchase decision-making criterion for consumers, as it is usually associated with vitamin content (Oliveira, 1996).

The use of natural pigments has increased due to consumer preference and to legal restriction in countries that have banned the addition of synthetic coloring in feeds and foods.

One important natural pigment is annato (Bixa orellana L.) because several tones can be obtained from its seed, from yellow to red up to 
tan. Studies have been carried out on the effects of annato, which is rich in bixin, on yolk pigmentation of layer eggs, particularly when the main dietary energy sources used instead of yellow corn have low pigmenting activity, such as sorghum, broken rice, millet, cassava meal, etc.(Oliveira, 2004).

Curcumin is the main pigment present in turmeric roots (Turmeric longa L.), and it is also known and saffron. In addition of its utilization as food color and spice, it has antioxidant and antimicrobial properties, which allows it to be applied in cosmetics, textiles, pharmaceutics, and foods (Pruthi, 1980). Turmeric has been increasingly used in food applications, such as in starch for cake preparations and as color in pasta, mustard, ice cream, cheese, egg, margarine, and meats.

Considering the few studies carried out in Brazil on the use of pigments in eggs, this study aimed at evaluating the effect of curcumin and bixin on the performance and egg quality of second-cycle layers fed diets with $50 \%$ low-tannin sorghum replacing corn and the time how long these natural pigments take to pigment and disappear, when removed from the diet, from the egg yolk.

\section{MATERIALS AND METHODS}

In this experiment, 144 Hy-Line ${ }^{\circledR}$ Brown layers, were evaluated after forced molting, to three 28day periods. Birds were distributed in 24 cages $(1.00 \mathrm{~m}$ long $\times 0.45 \mathrm{~m}$ deep $\times 0.40 \mathrm{~m}$ high) divided in three compartments, housing two birds each. After forced molting, all birds were submitted to the same management and feeding conditions until the peak of lay, after which they grouped as a function of similar body weight and egg production, around 90 weeks of age. Layers were then distributed in a completely randomized experimental design with six replicates of six birds each per treatment, and fed diets formulated with low-tannin sorghum replacing $50 \%$ corn with the addition or not of natural pigments. The following treatments were applied: Control - reference diet based on $50 \%$ corn and $50 \%$ low-tannin sorghum; AS - Reference diet $+2 \%$ annato seed; TR - Reference diet $+2 \%$ turmeric root; and ASTR - Reference diet + $1 \%$ annato seed $+1 \%$ turmeric root.

During the entire experimental period, layers were submitted to the same management and feeding conditions, with water and fee offered ad libitum.

Feeds were formulate to contain equal protein, energy, available phosphorus, calcium, methionine, sulfur amino acid, and lysine levels, according to the recommendations of Rostagno et al. (2005), except for pigment content (Table 1). Sorghum replaced $50 \%$ of corn in all diets. Annato seeds and turmeric roots were washed, dried for $24 \mathrm{~h}$ in a forced-ventilation oven at $75 \pm 2{ }^{\circ} \mathrm{C}$, ground, and sieved.

Table 1 - Ingredient composition and calculated nutritional composition of the experimental diets

\begin{tabular}{|c|c|c|c|c|}
\hline \multirow{2}{*}{ Ingredient (\%) } & \multicolumn{4}{|c|}{ Treatment $^{1}$} \\
\hline & Control & AS & TR & ASTR \\
\hline Corn $(8 \% \mathrm{CP})$ & 32.24 & 31.78 & 31.86 & 31.67 \\
\hline Sorghum (11\% CP) & 33.95 & 32.79 & 32.72 & 32.89 \\
\hline Soybean meal (45\% CP) & 22.88 & 22.93 & 22.89 & 22.91 \\
\hline Annato $(11 \% \mathrm{CP})$ & - & 2.0 & - & 1.0 \\
\hline Turmeric ( $8 \% \mathrm{CP})$ & - & - & 2.0 & 1.0 \\
\hline Calcitic limestone & 7.99 & 7.98 & 7.97 & 7.97 \\
\hline Dicalcium phosphate & 1.54 & 1.52 & 1.52 & 1.52 \\
\hline Salt & 0.35 & 0.37 & 0.37 & 0.37 \\
\hline Vitamin supplement ${ }^{2}$ & 0.10 & 0.10 & 0.10 & 0.10 \\
\hline Mineral supplement ${ }^{3}$ & 0.10 & 0.10 & 0.10 & 0.10 \\
\hline DL-Methionine 99\% & 0.16 & 0.17 & 0.17 & 0.17 \\
\hline Washed sand & 0.69 & 0.26 & 0.30 & 0.30 \\
\hline TOTAL & 100.00 & 100.00 & 100.00 & 100.00 \\
\hline \multicolumn{5}{|l|}{ Calculated composition } \\
\hline Metabolizable energy (kcal/kg) & 2800 & 2800 & 2800 & 2800 \\
\hline Crude protein (\%) & 16.09 & 16.09 & 16.09 & 16.09 \\
\hline Methionine (\%) & 0.56 & 0.56 & 0.56 & 0.56 \\
\hline Lysine (\%) & 0.74 & 0.74 & 0.74 & 0.74 \\
\hline Methionine + Cystine (\%) & 0.68 & 0.82 & 0.82 & 0.82 \\
\hline Calcium (\%) & 4.00 & 4.00 & 4.00 & 4.00 \\
\hline Available phosphorus (\%) & 0.38 & 0.38 & 0.38 & 0.38 \\
\hline
\end{tabular}

1 - Reference diet $+2 \%$ turmeric root and ASTR - Reference diet $+1 \%$ annato seed $+1 \%$ turmeric root. 2 - Product composition: Vitamin $A$, vitamin $D 3$, vitamin $E$, vitamin $K$, vitamin $B 1$, vitamin $B 2$, vitamin $B 6$, vitamin $B 12$, niacin, folic acid, pantothenic acid, sodium selenide, vehicle Q.S.P. Guaranteed levels per kg product: Vitamin A 10,000,000 IU, Vitamin D3 2,500,000 IU, Vitamin E 6,000 IU, Vitamin K 1,600 mg, Vitamin B12 $11,000 \mathrm{mg}$, niacin $25,000 \mathrm{mg}$, folic acid $400 \mathrm{mg}$, pantothenic acid $10,000 \mathrm{mg}$, selenium $300 \mathrm{mg}$, antioxidant $20 \mathrm{~g}$. 3 - Product composition: manganese monoxide, iron sulfate, copper sulfate, calcium iodide, vehicle Q.S.P. Guaranteed levels per kg product: manganese $150,000 \mathrm{mg}$, zinc $100,000 \mathrm{mg}$, iron $100,000 \mathrm{mg}$, copper $16,000 \mathrm{mg}$, iodine $1.500 \mathrm{mg}$.

Eggs were collected daily in the morning and average egg production was obtained by dividing the total number of produced eggs (intact, broken, cracked, and misshapen eggs) by the number of birds alive in each experimental unit. Feed conversion ratio per $\mathrm{kg}$ was determined by dividing total feed intake by egg weight, and expressed as $\mathrm{kg}$ feed/ $\mathrm{kg}$ eggs. Feed conversion ratio per dozen was obtained by dividing average feed intake per dozen of eggs produced. Average egg weight of an experimental unit was calculating by dividing total egg weight by the number of egg produced. Mortality rate was obtained by 
subtracting the number of hens alive at the end of the experiment from the number of housed hens, and expressed as percentage.

In order to determine yolk, albumen, and eggshell weights and eggshell thickness, two intact eggs per experimental unit were randomly collected every $28 d$ for three consecutive days. After duly identified and weighed in a $0.01 \mathrm{~g}$ precision scale, eggs were broken, and their yolks were manually separated and weighed. Eggshells were dried in a forced-ventilation oven for $24 \mathrm{~h}$ at $105^{\circ} \mathrm{C}$ and weighed. Albumen weight was determined as the difference between egg weight and eggshell and yolk weights. Egg specific gravity was obtained by immersing the eggs in different saline solution, with densities ranging from $1.050 \mathrm{~g} / \mathrm{cm}^{3}$ to $1.100 \mathrm{~g} / \mathrm{cm}^{3}$, and recording the solution in which the egg floated.

Eggshell thickness, including egg membranes was measured in three different points in the egg equatorial region using an external micrometer (Mitutoyo, model 103-137), with 0-25 mm range, $0.01 \mathrm{~mm}$ reading, and $0.002 \mathrm{~mm}$ accuracy. Eggshell thickness was determined as the average value of three measurements, according to the methodology described by Nordstrom \& Ousterhout (1982).

Yolk color was analyzed at Laboratório do Pólo Regional do Leste Paulista, APTA, using a subjective and a direct (instrumental methodologies). In the subjective method, two yolks per replicate were placed in Petri dishes on a white background on days $0,3,7$ 10, 14, 21, 28 and 56. At the end of the experiment, the pigments were withdrawn from the diets, and eggs were collected again on days $0,3,7,10$ and 28 after withdrawal to determine the time required for yolk depigmentation. Yolk color was determined using the DSM ${ }^{\circledR}$ yolk color fan by the same trained observer, who attributed an average score between 1 and 15, according to the description of Galobart et al. (2004).

Yolk color was determined by direct method in three yolks per replicate from eggs collected on day

Table 2 - Performance of layers fed diets based on corn and low-tannin sorghum containing different inclusion levels of annato seed and turmeric root.

\begin{tabular}{lccccccc}
\hline Treatment & Egg weight & \% lay & Egg mass & $\begin{array}{c}\text { Feed intake } \\
\text { (g/bird/day) }\end{array}$ & FCR/dz & FCR/kg & Mortality \\
\hline Control & 70.62 & $68.16 \mathrm{a}$ & 49.22 & 123.35 & 2.17 & 2.51 & 1.86 \\
AS & 69.83 & $70.00 \mathrm{ab}$ & 50.29 & 123.14 & 2.12 & 2.46 & 2.73 \\
TR & 69.91 & $71.83 \mathrm{ab}$ & 50.40 & 122.63 & 2.05 & 2.44 & 0.71 \\
ASTR & 70.89 & $74.83 \mathrm{~b}$ & 52.81 & 127.71 & 2.05 & 2.42 & 1.29 \\
P & $\mathrm{NS}$ & $<0.05$ & $\mathrm{NS}$ & $\mathrm{NS}$ & $\mathrm{NS}$ & $\mathrm{NS}$ & $\mathrm{NS}$ \\
CV (\%) & 2.45 & 4.77 & 5.37 & 3.15 & 3.65 & 4.06 & 98.46 \\
\hline
\end{tabular}

Means followed by different letters in the same column are statistically different by the test of Tukey. 1 - Feed conversion ratio per dozen eggs (FCR/dz). 2 - Feed conversion ratio per kg eggs (FCR/kg).
56, using tristimulus colorimetry of the CIELAB system (portable spectrophotometer MINOLTA, model CM 508d), with D65 illuminant and $10^{\circ}$ illuminating angle. The results are expressed in the coordinates $L^{*}$ (lightness), $h$ (tone) and $C$ * (chromaticity).

Yolk pigmentation and depigmentation data were submitted to analysis of variance and analysis of regression, and means compared by the test of Tukey at $5 \%$ significance level. Data obtained for other parameters were submitted to analysis of variance (ANOVA), and means compared by the test of Tukey at $5 \%$ significance level, using SISVAR statistical package.

\section{RESULTS AND DISCUSSION}

Average minimum and maximum environmental temperatures inside the poultry house during the experimental period were $19.5 \pm 2.11$ and $31.7 \pm 2.74$ ${ }^{\circ} \mathrm{C}$, respectively.

The inclusion of annato seed and turmeric root in the diet did not affect ( $p>0.05$ ) egg weight, egg mass, feed intake, FCR/dz, FCR/kg or mortality (Table $2)$. These results are consistent with the findings of Garcia et al. (2009), who used 0.5, 1, 1.5, 2.0, and $2.5 \%$ annato seed inclusion levels in diets based on corn and sorghum. Braz et al. (2007) added 0.0, 0.5, $1.0,1.5$ or $2 \%$ residual annato seeds to diets based on sorghum, replacing 100\% corn, and did not observe any differences in layer performance. On the other hand, Queiroz (2006) and found reduced feed intake when the dietary inclusion of annato exceeded $3 \%$. That author attributed the low feed intake of the birds fed sorghum with 6, 9 and $12 \%$ annato meal to the longer dwelling time of the feed in the digestive tract due to the high fiber content on annatto. Curvelo et al. (2009) did not find any significant differences $(p<0.05)$ in feed intake, feed conversion ratio, average egg weight, or egg loss when annato extract and turmeric were added to layer feeds at 0.1 and $0.2 \%$ inclusion levels. In a study where broilers were fed $20 \mathrm{mg} / \mathrm{bird} /$ day turmeric and annato, Silva et al. (2001) concluded that these ingredients did not influence weight gain and feed conversion ratio on days 7,14 or 21 .

Egg production percentage was significantly affected by the treatments $(p<0.05)$, with layers fed $1 \%$ turmeric root and 1\% 
annato seed presenting higher egg production as compared to the control birds, which were not fed these natural pigments. The other treatments presented intermediate values and were not different. These results are contrasting with those obtained by Curvelo et al. (2009), who did not find significant differences in egg production when lower levels of annato extract and turmeric were added to layer diets. Conversely, Garcia et al. (2009), observed lower egg production when dietary annato seed inclusion exceeded $1.5 \%$, whereas, Silva et al. (2000) comparing the effect of annato residue dietary supplementation annato (4, 8 and $12 \%)$ in sorghum-based diets (40\%) obtained better results with the level of $12 \%$. Those authors did not observe any effect on egg specific gravity or egg weight; however, a linear increase in egg production was obtained, with the best results when $12 \%$ annato was added to the diet.

Egg quality parameters were not influenced ( $p>0.05$ ) by the dietary treatments (Table 3 ). The results obtained in the present experiment are similar to those found by Silva et al. (2000) and Garcia et al. (2009). Braz et al. (2007) worked with different annato byproducts and levels, and did not find statistical differences in the studied egg quality parameters. In a study with annato extract and turmeric, Curvelo et al. (2009) also did not observe any influence on egg quality traits. In a study on the inclusion of paprika, marigold flowers and annato in layer diets, Lokaewmanee et al. (2010) did not observe any significant effects on Haugh units, egg weight, eggshell weight, yolk weight, albumen weight, or eggshell thickness.

Table 3 - Egg quality of layers fed diets based on corn and lowtanning sorghum containing different inclusion levels of annato seed and turmeric root.

\begin{tabular}{lcccc}
\hline Treatment & SEG $^{1}$ & Yolk \% & Albumen \% & Eggshell \% \\
\hline Control & 1.077 & 25.52 & 65.84 & 8.88 \\
AS & 1.077 & 25.31 & 66.20 & 8.55 \\
TR & 1.074 & 25.79 & 66.05 & 8.16 \\
ASTR & 1.077 & 25.75 & 65.67 & 8.84 \\
P & NS & NS & NS & NS \\
CV $(\%)$ & 0.67 & 8.42 & 3.15 & 9.90 \\
\hline
\end{tabular}

1 - SEG = specific egg gravity. Non-significant effect $(P>0.05)$.
Results of the analyses of variance detected significant effects of all treatments $(p<0.05)$ on the parameter yolk color. The analysis of regression for the effect of the number of days of pigment supply indicated an increasing linear effect on yolk color of the treatments AS and ASTR, which contained annato (Table 4). Yolk color intensity increased with duration of pigment supply in these treatments $(p<0.05)$. The treatment that included the highest level of annato (AS) promoted more intense pigmentation on day 28 as compared to day 10 and day 7, suggesting higher pigment deposition in the yolk after day 10 of $2 \%$ annato supplementation in the feeds. The treatment ASTR, which included $1 \%$ annato and $1 \%$ turmeric, yolk pigmentation was also more intense on day 28 than on days 21 or 7 , indicating that the use of curcumin together with annato, or that a lower levels of annato (1\%) also pigments egg yolk.

The control and TR treatments, which did not contain annato, despite their significant effects on yolk color as detected by analysis of variance, presented quadratic regression results, indicating that there was no increasing linear effect on yolk color during pigment supply, as occurred when annato was supplemented in the diet. The curve starts with yolk color score 6.5 on day zero (due to the effect of the corn-soybean meal diet supplied until the day before the experiment started); however, this score was reduced and became stable on day 4, which suggests that when the corn-soybean meal diet was changed for corn-sorghum-soybean meal turmeric was not able to maintain the previous yolk pigmentation, presenting the same behavior as the control treatment, which was not supplemented with pigments. Oliveira et al. (2007) included annato in Japanese quail diets and observed an intensification of yolk color when pigments were continuously added to the feed for at least 21 days. The authors also observed that yolk pigmentation on day 28 was higher than on days 21,7 and 14, independently of pigment dietary level. Curvelo et al. (2009) only observed changes in yolk color (score 8.39 ) when using $0.2 \%$ extrato annato extract; the other treatments $(0.1 \%$ annato and 0.1 and $0.2 \%$ turmeric) resulted in the same yolk

Table 4 - Regression equations of yolk color of the eggs of layers fed diets based on corn and low-tannin sorghum containing different inclusion levels of annato seed and turmeric root.

\begin{tabular}{|c|c|c|c|c|c|c|c|c|c|}
\hline \multirow{2}{*}{ Treatment } & \multicolumn{7}{|c|}{ Yolk color score on different observation day } & \multirow{2}{*}{ Equation } & \multirow{2}{*}{$\mathbf{R}^{2}(\%)$} \\
\hline & 0 & 3 & 7 & 10 & 14 & 21 & 28 & & \\
\hline Control & 6.5 & 5.8 & 4.6 & 4.4 & 4.1 & 4.0 & 4.0 & $Y=6.4355-0.2595 X+0.006312 X^{2}$ & 97.02 \\
\hline AS & 6.5 & 8.5 & 9.2 & 9.3 & 9.5 & 9.7 & 11.8 & $Y=7.5125+0.1434 X$ & 81.45 \\
\hline TR & 6.5 & 5.6 & 4.6 & 4.3 & 4.2 & 4.2 & 4.2 & $Y=6.3237-0.2507 X+0.006409 X^{2}$ & 94.17 \\
\hline ASTR & 6.5 & 7.5 & 8.0 & 8.1 & 8.3 & 8.7 & 10.6 & $Y=6.8741+0,1153 X$ & 90.15 \\
\hline
\end{tabular}


color, but it must be mentioned that the basal diet was based in corn and soybean meal.

When the pigments were withdrawn from the feed, the analysis of variance detected significant effects only in treatments AS and ASTR, which contained annato $(p<0.05)$ only on the parameter yolk color. The analysis of regression for the effect of days of supply of diets with pigments indicated a decreasing linear effect on the yolk color of the eggs of layer fed treatments AS and ASTR (Table 5). Three days after pigments were withdrawn from the feeds, yolk color faded $(p<0.05)$. $\mathrm{h}$ angles mean that yolk color is closer to yellow (TR), whereas lower angles indicate that the color is closer to red. The results showed that yolks resulting from the treatments containing annato presented lower $h$ angle values, and therefore, their color was closer to red as annato dietary inclusion increased, whereas it increased in the other treatments, going from orange in treatment ASTR from yellow in the Control and TR treatments.

The color parameter $C$, which represent average sample chromaticity, defined the saturation and

Table 5 - Regression equations of yolk color of the eggs of layers fed diets based on corn and low-tannin sorghum containing different pigment inclusion levels.

\begin{tabular}{|c|c|c|c|c|c|c|c|}
\hline \multirow{2}{*}{ Treatment } & \multicolumn{5}{|c|}{ Yolk color score according to day of observation } & \multirow{2}{*}{ Equation } & \multirow{2}{*}{$\mathbf{R}^{2}(\%)$} \\
\hline & 0 & 3 & 7 & 10 & 28 & & \\
\hline AS & 12.1 & 10.5 & 4.9 & 4.2 & 4.0 & $Y=12.6239-1.1877 X+0.0314 X^{2}$ & 95.73 \\
\hline ASTR & 9.8 & 9.1 & 4.4 & 4.1 & 4.0 & $Y=10.3226-0.8804 X+0.0233 X^{2}$ & 92.38 \\
\hline
\end{tabular}

The control and TR treatments did not maintain yolk color and therefore, did not present significant results.

Treatments AS and ASTR presented decreasing linear effect on yolk color after 7 days of withdrawal from the feeds. Egg yolks maintained their color up to three days after pigment withdrawal and then stabilized at colorimeric score 4.0. This shows that when annatto was removed from the diet, only the diet $50 \%$ corn replacement by sorghum was not able to maintain the previous yolk pigmentation after day 3 .

The coordinate $L^{*}$ significantly decreased $(p<0.05)$ as a function of increasing dietary annato levels. High luminosity values $\left(L^{*}\right)$ indicate lighter yolks, which are opposite to consumers' demands as darker yolks are associated to healthier, more natural eggs.

Table 6 - Means of the coordinates luminosity, tone, and chromaticity of raw eggs of layers fed diets with different natural pigments.

\begin{tabular}{lccc}
\hline \multirow{2}{*}{ Treatment } & \multicolumn{3}{c}{ Raw yolk } \\
\cline { 2 - 4 } & $\mathbf{L}^{*}$ & $\mathbf{h}$ & $\mathbf{C}^{*}$ \\
\hline Control & $55.24 \mathrm{c}$ & $78.90 \mathrm{~b}$ & $47.22 \mathrm{ab}$ \\
TR & $54.66 \mathrm{c}$ & $83.57 \mathrm{a}$ & $38.38 \mathrm{~b}$ \\
AS & $45.55 \mathrm{a}$ & $65.64 \mathrm{~d}$ & $49.38 \mathrm{a}$ \\
ASTR & $49.89 \mathrm{~b}$ & $72.82 \mathrm{c}$ & $47.18 \mathrm{ab}$ \\
P & $>0.05$ & $>0.05$ & $>0.05$ \\
CV & 4.52 & 5.68 & 3.97 \\
\hline
\end{tabular}

$\mathrm{L}^{*}$ (luminosity), $\mathrm{h}$ (tone) and $\mathrm{C}^{*}$ (chromaticity). Means followed by different letters in the same column are statistically different by the test of Tukey.

The parameter $h$, which defines the basic color of the samples and represents average yolk tone, was also significantly different among treatments. Higher intensity of the color defined in h (McGuirre, 1992). High chromaticity indicates higher color saturation and intensity. Chromaticity in the AS treatment was significantly higher as compared to the the treatment using only turmeric in the diet (TR), indicating that the color is more intense in yolk of the eggs of layers fed diets with $2 \%$ annato. The lowest saturation values (C) indicate the presence of white color in the yolks, as observed in the eggs of layers fed feeds containing turmeric as pigment.

Similar results were observed by Harder et al. (2008) with the inclusion of $2 \%$ annato seeds in layer diets.

\section{CONCLUSIONS}

In diets where sorghum replaced $50 \%$ of corn, the inclusion of turmeric and annato affected egg production and yolk color of the eggs of layers in their second production cycle. Yolk color in treatments containing annato seed was more saturated, more intense, and closer to red. Yolk pigmentation started on day 7 and was intensified on day 28. Dried turmeric root did not provide good yolk pigmentation, with a higher presence of white color in the yolk. The withdrawal of pigments from the diet results in color fading after 3 days.

\section{REFERENCES}

Assuena V, Filardi RS, Junqueira OM, Casartelli EM, Laurentiz AC, Duarte KF. Substituição do milho pelo sorgo em rações para poedeiras comerciais formuladas com diferentes critérios 
de atendimento das exigências em aminoácidos. Ciência Animal Brasileira 2008; 9(1):93-99.

Bartov I, Bornstein S. Studies on egg yolk pigmentation: Effect of ethoxiquin on xanthophylls within and among genetic sources. Poultry Science 1980; 50:1460-1461.

Braz NM, Fuentes MFF, Freitas ER, Sucupira FS, Moreira RF, Lima RC. Semente residual do urucum na alimentação de poedeiras comerciais: desempenho e características dos ovos. Acta Scientiarum Animal Science 2007; 29(2):129-133.

Casartelli EM, Filardi RS, Junqueira OM, Laurentiz AC, Assuena V, Duarte KF. Commercial laying hen diets formulated according to different recommendations of total and digestible amino acids. Revista Brasileira de Ciência Avícola 2005; 7(3):177-180.

Curvelo ER, Geraldo A, Silva LM, Santos TA, Vieira Filho JA, Pinto ERA, Oliveira MLR, Ferreira CB. Níveis de inclusão de extrato de urucum e açafrão em dietas para poedeiras semipesadas e seus efeitos sobre o desempenho e coloração da gema dos ovos. Anais da II Semana de Ciência e Tecnologia do IFMG; II Jornada Científica; 2009; Bambuí; Minas Gerais. Brasil. [citado 2011 Jan 06]. Disponível em: http://www.cefetbambui.edu.br/sct/trabalhos/ Recursos\%20Naturais/155-PT-1.pdf.

Galobart J, Sala R, Rincón-Carruyo X, Manzanilla EG, Vil B, Gasa J. Egg yolk color as affected by saponified oleoresin of red pepper (Capsicum annuum) fed to laying hens. Poultry Science 2004; 69:462-470.

Garcia EA, Molino AB, Berto DA, Pelícia K, Osera RH, Faitarone $A B G$. Desempenho e qualidade dos ovos de poedeiras comerciais alimentadas com semente de urucum (Bixa orellana) moída na dieta. Veterinária e Zootecnia 2009; 16 (4):689-697.

Harder MNC, Brazaca SGC, Savino VJM, Coelho AAD. Efeito de Bixa orellana na alteração de características de ovos de galinhas. Ciência e Agrotecnologia 2008; 32(4):1232-1237.

Lokaewmanee K, Yamauchi K, Komori T, Saito K. Effects on egg yolk colour of paprika or paprika combined with marigold flower extracts. Italian Journal of Animal Science 2010; 9 (4):356-359.

McGuirre R. Reporting of objective color measurements. Hort Science 1992; 17(12):1254-1255.

Nordstrom JO, Ousterhout LE. Estimation of shell weight and shell tickeness from egg specific gravity and egg weight. Poultry Science 1982; 61:1991-1995.

Oliveira NTE, Fonseca JB, Soares RTRN, Ferreira KS, Thiébaut JTL. Pigmentação das gemas de ovos de codornas japonesas alimentadas com rações contendo colorífico. Ciência e Agrotecnologia 2007; 31(5):1525-1531.

Oliveira BL. Aspectos atuais e futuros da nutrição de poedeiras. Caderno técnico da Escola de Veterinária- UFMG 1996; 17:5-10.

Oliveira NTE. Energia metabolizável de alimentos e qualidade de ovos e carne de codornas japonesas alimentadas com rações contendo colorífico do urucum e niacina suplementar [tese].
Campos dos Goytacazes (RJ): Universidade Estadual do Norte Fluminense; 2004.

Pruthi JS. Spices and condiments: chemistry, microbiology, technology. New York: Academic Press; 1980.

Queiroz EA. Níveis de farelo de urucum (Bixa orellana L.) em rações à base de sorgo para poedeiras comerciais [dissertação]. Rio de Janeiro (RJ): Universidade Federal Rural do Rio de Janeiro; 2006.

Rostagno HS, Albino LFT, Donzele JL, Gomes PC, Oliveira RF, Lopes DC, Ferreira AS, Barreto SLT. Tabelas brasileiras para aves e suínos: composição de alimentos e exigências nutricionais. 2 ed. Viçosa: UFV; 2005

Silva JAH, Albino LF, Godói MJS. Efeito do extrato de urucum na pigmentação da gema dos ovos. Revista Brasileira de Zootecnia 2000; 29(5):1435-1439.

Silva RR, Oliveira TT, Nagem TJ, Pinto AS, Albino LFT, Almeida MR, Leão MA. Curcumina e norbixina: ação no metabolismo lipídico de aves domésticas. Medicina 2001; 34:177-182. 